\begin{tabular}{|c|c|c|}
\hline \multirow[t]{2}{*}{7} & $\begin{array}{l}\text { International Journal of Current Research in } \\
\text { Biosciences and Plant Biology }\end{array}$ & \\
\hline & Volume $4 \bullet$ Number 6 (June-2017)• ISSN: 2349-8080 (Online) & \\
\hline PUBLISHERS & Journal homepage: www.ijcrbp.com & \\
\hline
\end{tabular}

\title{
Diversity and Distribution of Endophytic Fungi in Different Prunus africana (Hook. f.) Kalkman Provenances in Cameroon
}

\author{
Gloria Maloba Ntuba-Jua*, Afui Mathias Mih and Eneke Esoeyang Tambe Bechem
}

Department of Botany and Plant Physiology, Faculty of Science, University of Buea, P. O. Box 63, Buea, Cameroon

*Corresponding author.

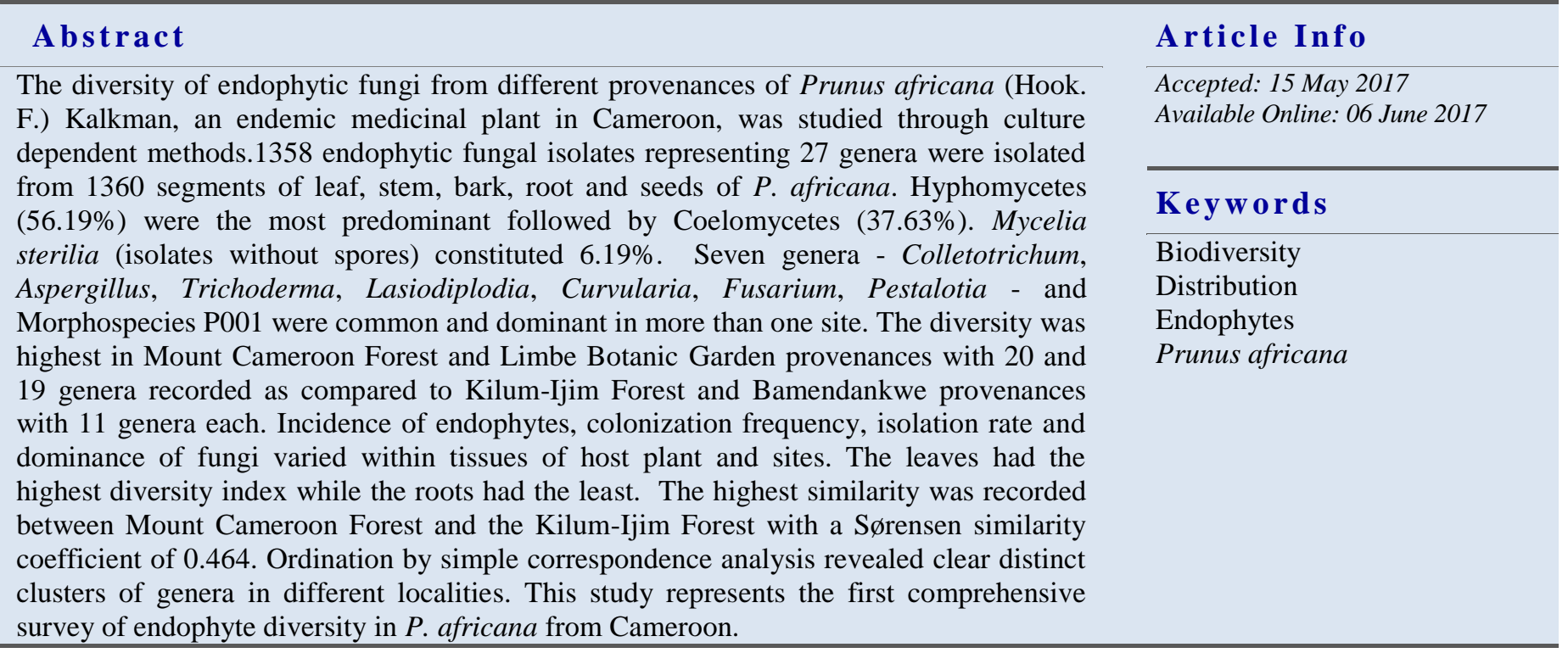

\section{Introduction}

Prunus africana (Hook. f.) Kalkman, commonly known as Pygeum or African cherry, belongs to the Rosaceae family. It is a medium to large, evergreen tree with a spreading crown of 10 to $20 \mathrm{~m}$. It is used by traditional medical practitioners for the treatment of over 45 ailments (Stewart, 2003) in Cameroon and sub-Sahara Africa. In modern medicine, Prunus bark has been used for the treatment of Benign Prostrate Hyperplasia (BPH), Prostate Gland Hypertrophy (PGH), (enlarged prostate glands) and male baldness (Bombardelli and Morazzoni, 1997). This is possible because of its ability to produce secondary metabolites which are believed to have bioactivity against these ailments. These extracts from the bark have been patented and are being marketed internationally in a number of pharmacies (Sunderland and Obama, 1999; Schippmann, 2001), providing a market value of around US $\$ 150$ million per annum (Cunningham et al.., 1997). The ready market for the sale of Prunus bark has led to the indiscriminate harvesting of the plant. The uncontrolled exploitation, illegal harvesting 
using inappropriate techniques and poor timing of harvesting (Ingram, 2007) have contributed to making this plant endangered. It is now listed as endangered by International Union for the Conservation of Nature (IUCN) and under Appendix II of Convention on International Trade in Endangered Species (CITES) list of endangered species of Wild Fauna and Flora, for regulation of trade from wild harvest.

Many endophytes have been recognized to have the potential to synthesize similar bioactive metabolites as their respective host (medicinal) plants (Aly et al., 2010; Kharwar et al., 2011; Kusari et al., 2012; Strobel, 2002; Strobel et al., 2004). Identification of such endophytes in Prunus could be an alternative source of such metabolites and thus serve as a conservation measure for Prunus africana by reducing dependence on Prunus bark for such metabolites. This requires a thorough knowledge of the diversity of the endophytic mycoflora of $P$. africana. Despite several studies on this plant relating to inventories (Ewusi et al., 1992), ecology (Stewart, 2001), cultivation potential (Dawson et al., 2000), genetic characteristics (Dawson and Powell, 1999), traditional uses (Stewart, 2001), chemical constituents (Fourneau et al., 1996), bark yield studies (Ewusi et al., 1997), and harvest effects (Cunningham and Mbenkum, 1993; Stewart, 2001), there has been no report on the endophytic fungi associated with it. This study therefore sought to elucidate the diversity of endophytic fungi in $P$. africana and how these are distributed indifferent provenances and tissue types of the plant in Cameroon.

\section{Materials and methods}

\section{Sampling}

The study was carried out from March 2011 to January 2013.Samples were collected from four sites in Cameroon where major production of $P$. africana occurs viz., Mount Cameroon Forest (MCF) and the Medicinal Plant Collection in the Limbe Botanic Garden (LBG) in the South West Region and Mount Kilum-Ijim forest (KIF) and Bamendankwe (BDA) in the Bamenda highlands of North West region of Cameroon. These sites were selected to adequately represent the genetic base (Dawson and Powell, 1999) and to target a wide variety of ecotypes taken from a wide geographic range of Prunus population growing in the wild and those cultivated. At each site, healthy, fresh mature leaves, stems, bark and roots of $P$. africana under study were collected in three randomly chosen directions. Fresh-cut ends of plant samples were wrapped in moist paper towels and sealed in ziplock bags to avoid desiccation. Seeds were collected only from Mount Kilum-Ijim forest. No fruiting was observed in the other sampling sites at the time of collection. All collected materials were processed within $72 \mathrm{hrs}$ of collection.

\section{Sample processing, isolation and identification of endophytic fungi}

All sample collected were brought to the Rubber Pathology Laboratory, Institute of Agricultural Research for Development (IRAD), Ekona for processing. Plant samples (leaf, stem, bark, roots and seeds) were thoroughly washed under running tap water to remove the surface adherents. The inner tissues were each carefully cut into small segments (approx. $5 \mathrm{~mm}$ ) with a pair of scissors and air dried before surface sterilization. Surface sterilization of segments was done following a modified method of Arnold et al. (2001). The segments were sequentially immersed in $95 \%$ ethanol for $1 \mathrm{~min}$, then in aqueous sodium hypochlorite $(6 \%$ available chlorine) for three to five minutes, followed by a $30 \mathrm{~s}$ immersion in $95 \%$ ethanol. They were finally rinsed in three changes of sterile distilled water for three minutes. Surface sterilized segments were blotted and dried with sterile filter paper. The efficacy of the sterilization procedure was confirmed following the method of Schulz et al. (1993).

Five surface-sterilized tissue segments $(5 \mathrm{~mm})$ were placed on each petri-plate containing different mycological media (Potatoes Dextrose Agar - PDA; Potatoes Carrot Agar - PCA; Malt Extract Agar - MEA; Prunus Extract Agar - PEA) to isolate the maximum number of endophytic fungi from host plant. The media were supplemented with stock antibiotic solution composed of $0.02 \mathrm{~g}$ each of streptomycin, chloramphenicol and penicillin in $10 \mathrm{~mL}$ sterile distilled water (Vega et al., 2006) at the rate of $0.1 \%(\mathrm{v} / \mathrm{v})$ to suppress bacterial growth. The plates, sealed with paraffin, incubated at room temperature and were observed daily for endophytic fungal growth for 2 - 3 weeks. Hyphal tips growing out of the plant segments were sub cultured into fresh PDA plates. For inducing sporulation, each isolate was separately inoculated on PDA, PCA and Water Agar (WA) plates, respectively.

Fungi from the sporulation plates were mounted on slides in water and later in mounts containing 
lactophenol-cotton blue and sealed with nail varnish. They were then observed under the microscope. The fungal isolates were identified based on their cultural and micro-morphological characteristics of hyphae and reproductive structures following standard identification keys and using standard identification manuals (Barnett and Hunter, 1998; Watanabe, 2002). The fungal cultures that failed to sporulate were categorized as 'Mycelia sterilia' and sorted to morphospecies according to cultural characteristics (Lacap et al., 2003). All the purified isolates were maintained in PDA slant and in sterile distilled water and stored at $4{ }^{\circ} \mathrm{C}$.

\section{Data analysis}

Fungal occurrence was estimated by calculating the colonization frequency, isolation rate and percentage of dominant endophytes.

The colonization frequency (CF), expressed as percentage, was calculated according to Kumaresan and Suryanarayanan (2001) as follows:

$$
\% C F=\frac{N_{\text {CoI }}}{N_{t}} X 100
$$

Where, $\mathrm{CF}=$ Colonisation frequency;

$\mathrm{N}_{\text {col }}=$ the number of segments colonized by each fungus, and

$\mathrm{N}_{\mathrm{t}}=$ the total number of segments.

This was used for comparative purposes to compare the degrees of infection by endophytic fungi between different plant tissues within each location and from all locations.

The percentage of dominant endophytes $(D)$ was calculated based on the formula:

$$
D=\left(\frac{96 C F}{N_{\text {to }}}\right) X 100
$$

Where, $\mathrm{D}=$ percentage of dominant endophytes

$\% \mathrm{CF}=$ colonization frequency

$\mathrm{N}_{t o}=$ the total number of endophytes (Kumaresan and Suryanarayanan, 2001).

Isolation rate (IR), the measure of fungal richness of a sample (Photita et al., 2005), was calculated as:

$$
\mathrm{IR}=\frac{N_{i}}{N_{t}}
$$

Where, $\mathrm{N}_{\mathrm{i}}$ the number of isolates obtained from tissue segments

$\mathrm{N}_{\mathrm{t}}$ the total number of segments.

Relative frequency (\%) was calculated as:

$$
\% R F=\left(\frac{N_{g}}{N_{t}}\right) \times 100
$$

Where, $\mathrm{N}_{g}=$ total number of genera

$\mathrm{N}_{t}=$ the total number of taxa obtained from different plant tissues incubated.

Comparison in percentage of colony frequency in the different tissues (leaf, stem, bark, root, and seed) from different locations, were determined by computing Shannon-Wiener indices and Simpson's Diversity indices (1- Dominance).

The Shannon- Wiener biodiversity index $\left(\mathrm{H}^{\prime}\right)$ was calculated according to the formula:

$$
\mathrm{H}^{\prime}=-\sum_{i=1}^{k} P i X \ln P i \text {. }
$$

Where, $\mathrm{k}$ is the total number of same fungal species, and pi is the proportion of individuals that species $\mathrm{i}$ contributes to the total (Pielou, 1975).

$$
\text { The Simpson's Diversity }=1-\sum(\mathrm{pi})^{2} \text {. }
$$

Species evenness was calculated with the formula

$$
E=\frac{H^{r}}{H_{\max }}
$$

$\mathrm{H}^{\prime}$ is Shannon- Wiener biodiversity index

$\mathrm{H}_{\max }=\ln (\mathrm{S})$ : Maximum value of diversity possible for the number of species

Where, $S=$ the total number of species present in a sample $=$ (species richness) .

To describe the taxonomic affinity of endophytic fungi among the various parts of the P. africana, from the four different locations, Sørensen's similarity coefficient (Cs), was used to measure the similarity between pairs of samples (Arnold et al., 2000).

$$
\mathrm{Cs}=2 \mathrm{j} /(\mathrm{a}+\mathrm{b})
$$


Where, $\mathrm{j}$ is the number of fungal species coexisting in plants of both locations,

a is the total number of fungal species in plant at one location,

$\mathrm{b}$ is the total number of fungal species in plants in the other location.

(Cs) ranges from 0 (no taxa shared) 1 (all taxa shared). This was based on presence or absence of specific fungal species in both the locations compared (Kumar and Hyde, 2004).

Simple correspondence analyses were used to analyze the tissue unit and fungal species ordinations in order to verify the ecological interrelationships of endophyte species incidence and their abundance from Prunus tissues among locations in a single analysis. Minitab 16 software was used to carry out the correspondence analyses.

\section{Results}

\section{Composition of endophytic fungi}

The general pattern of isolation of endophytic fungi from $P$. africana is shown on Table 1 . Out of the total of 1,360 Prunus segments plated, 1,101 yielded 1358fungal isolates distributed across the provenances and organs. All leaf segments plated yielded fungal colonies, giving a colonization frequency of $100 \%$. Mount Cameroon Forest (MCF) provenance had the highest number of isolates while Limbe Botanic Garden (LBG) had the least. For each provenance, the leaf gave the highest number of isolates. The colonization frequency ranged from $72.5 \%$ in Limbe Botanic Garden (LBG) to $93.1 \%$ in Mount Cameroon Forest (MCF) provenance, giving an overall colonization frequency of $80.9 \%$. This gave an overall isolation rate of 0.99 colony per segment plated.

Table 1. Isolation parameters of endophytic fungi from Prunus africana provenances in Cameroon.

\begin{tabular}{|c|c|c|c|c|c|c|}
\hline Provenance & Tissue & $\begin{array}{l}\text { Segments } \\
\text { cultured }\end{array}$ & $\begin{array}{l}\text { Segments } \\
\text { with fungi }\end{array}$ & $\begin{array}{l}\text { Colonization } \\
\text { frequency }(\%)\end{array}$ & $\begin{array}{l}\text { Fungal } \\
\text { isolates }\end{array}$ & $\begin{array}{l}\text { Isolation } \\
\text { rate }\end{array}$ \\
\hline \multirow{5}{*}{$\begin{array}{l}\text { Limbe Botanic } \\
\text { Garden }\end{array}$} & Leaf & 80 & 80 & 100.0 & 123 & 1.54 \\
\hline & Stem & 80 & 67 & 83.8 & 67 & 0.84 \\
\hline & Bark & 80 & 32 & 40.0 & 32 & 0.40 \\
\hline & Root & 80 & 53 & 66.3 & 53 & 0.66 \\
\hline & Seed & 0 & 0 & - & - & - \\
\hline \multirow{6}{*}{$\begin{array}{l}\text { Sub Total } \\
\text { Mount Cameroon } \\
\text { Forest }\end{array}$} & & 320 & 232 & 72.5 & 275 & 0.86 \\
\hline & Leaf & 80 & 80 & 100.0 & 183 & 2.29 \\
\hline & Stem & 80 & 79 & 98.8 & 89 & 1.11 \\
\hline & Bark & 80 & 64 & 80.0 & 64 & 0.80 \\
\hline & Root & 80 & 75 & 93.8 & 75 & 0.94 \\
\hline & Seed & 0 & 0 & - & - & - \\
\hline \multirow{6}{*}{$\begin{array}{l}\text { Sub Total } \\
\text { Mount Kilum-Ijim } \\
\text { Forest }\end{array}$} & & 320 & 298 & 93.1 & 411 & 1.28 \\
\hline & Leaf & 80 & 80 & 100.0 & 142 & 1.75 \\
\hline & Stem & 80 & 46 & 57.5 & 46 & 0.58 \\
\hline & Bark & 80 & 55 & 68.8 & 55 & 0.69 \\
\hline & Root & 80 & 59 & 73.8 & 59 & 0.74 \\
\hline & Seed & 80 & 74 & 92.3 & 74 & 0.93 \\
\hline \multicolumn{2}{|l|}{ Sub Total } & 400 & 314 & 78.5 & 374 & 0.94 \\
\hline \multirow[t]{5}{*}{ Bamendankwe } & Leaf & 80 & 80 & 100.0 & 119 & 1.49 \\
\hline & Stem & 80 & 62 & 77.5 & 62 & 0.78 \\
\hline & Bark & 80 & 74 & 92.5 & 74 & 0.93 \\
\hline & Root & 80 & 41 & 51.3 & 41 & 0.51 \\
\hline & Seed & 0 & 0 & - & - & - \\
\hline \multirow{2}{*}{\multicolumn{2}{|c|}{$\begin{array}{l}\text { Sub Total } \\
\text { Total }\end{array}$}} & 320 & 257 & 80.3 & 296 & 0.93 \\
\hline & & 1360 & 1101 & 80.9 & 1358 & 0.99 \\
\hline
\end{tabular}

Of the 1358 endophytic isolates obtained, 1277 or $93 \%$ belonged either to Hyphomycetes or Coelomycetes while the remaining (7\%) represented Mycelia sterilia with variations among sites (Fig. 1). 


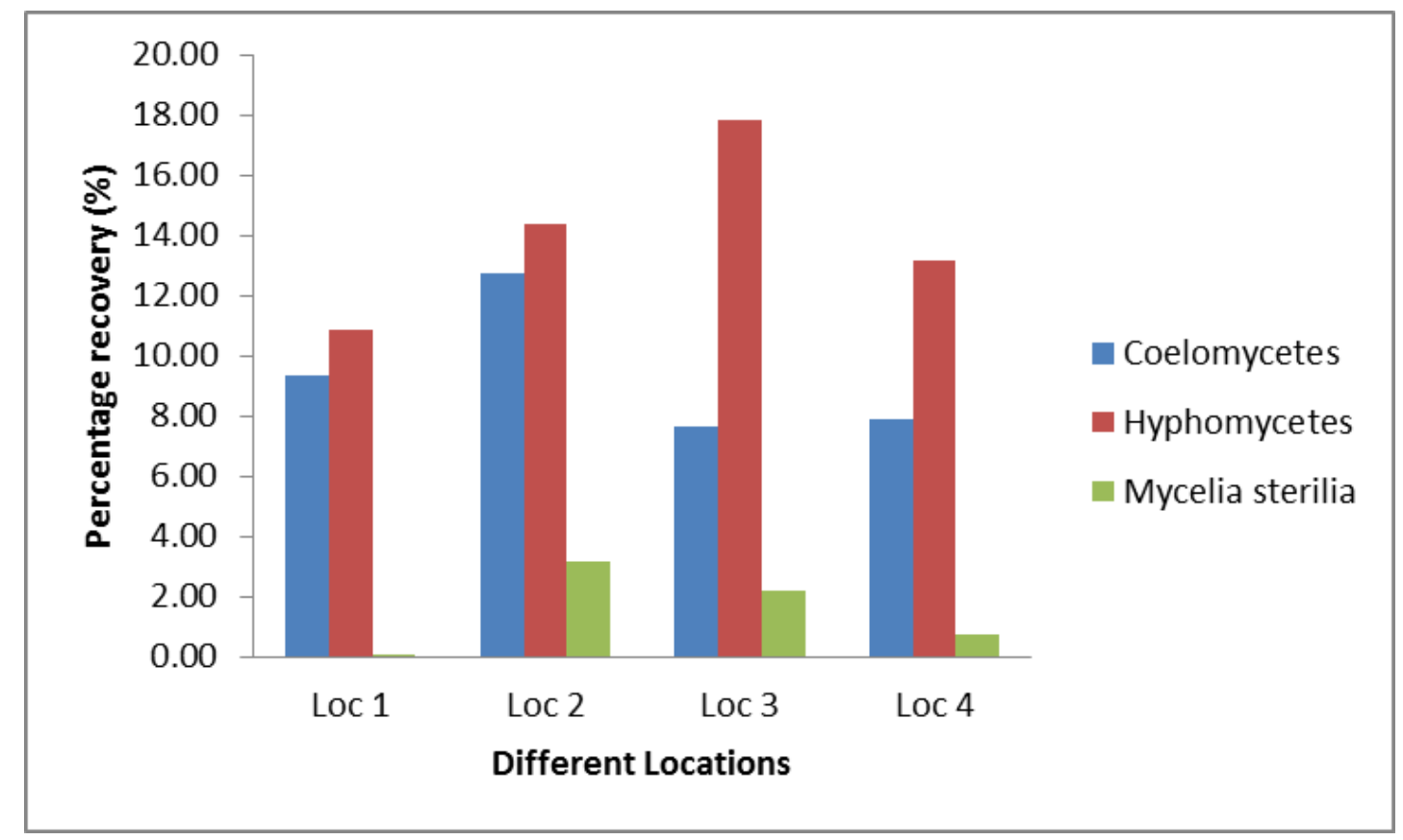

Fig. 1: Percentage recovery of different endophytic groups from four provenances of Prunus africana in Cameroon. Loc 1 = Limbe Botanic Garden, Loc 2 = Mount Cameroon Forest, Loc 3 = Mount KilumIjim Forest, Loc 4 = Bamendankwe.

The frequency of colonization of the various endophytic fungi from the four provenances is shown on Table 2 . Lasiodiplodia sp. was the most frequently occurring, and was isolated from material collected from all the four provenances. Penicillium sp. and Gloeosporium sp. were the least occurring, isolated from the bark from Mount Cameroon Forest and leaves from Limbe Botanic Garden, respectively. Colletotrichum and Trichoderma were the genera with the highest number (219 and 213 respectively) of isolates. There were two consistently recognizable Mycelia sterilia (Morphotype species 1 and 5) comprising 39 isolates $(2.87 \%)$.There were 13 genera with relative colonization frequency $>1 \%$ in at least one type of tissue category at each location (Table 3). These dominant endophyte genera include Colletotrichum $\mathrm{sp}$, Aspergillus sp, Trichoderma sp, Lasiodiplodia sp, Curvularia sp, 1, Fusarium sp, Pestalotia sp (2.94) and Morphospecies P001. The other identified rare genera (each $\leq 1 \%$ of isolates) were Cladosporium, Penicillium, Gloeosporium, Phyllosticta, Oidium, Mycogone, Gloecephalis, Geotrichum, Bispora, Aschochyta, Alternaria Acremonium, Paecilomyces, Phomopsis and Mycelia sterilia found mostly from Mount Cameroon Forest. The dominant genera within the sites are represented in Table 4. Eight were common and dominant in more than one site and also found to be distributed in most of the plant tissues giving a total of $80.34 \%$.

Table 2. Frequencies of occurrence of endophytic fungi isolated from various parts of Prunus africana from four provenances in Cameroon.

\begin{tabular}{|c|c|c|c|c|c|c|c|c|c|c|c|c|c|c|c|c|c|}
\hline \multirow{2}{*}{ Endophytic fungi } & \multicolumn{4}{|c|}{ LBG* } & \multicolumn{4}{|c|}{ MCF } & \multicolumn{5}{|c|}{ KIF } & \multicolumn{4}{|c|}{ BDA } \\
\hline & $\mathbf{L}^{* *}$ & $\mathbf{S}$ & B & $\mathbf{R}$ & $\mathbf{L}$ & $\mathbf{S}$ & $\mathbf{B}$ & $\mathbf{R}$ & $\mathbf{L}$ & $\mathbf{S}$ & B & $\mathbf{R}$ & Se & $\mathbf{L}$ & $\mathbf{S}$ & B & $\mathbf{R}$ \\
\hline \multicolumn{18}{|l|}{ Coelomycetes } \\
\hline Lasiodiplodia sp. & 10 & - & 5 & - & 30 & 34 & 15 & - & 32 & - & 6 & - & 28 & 10 & 8 & 18 & - \\
\hline Colletotrichum sp. 1 & 16 & 28 & - & 32 & - & - & - & - & - & - & - & - & - & - & - & - & - \\
\hline Colletotrichum sp. 2 & - & - & - & - & 24 & 16 & 8 & 15 & - & - & - & - & - & - & - & - & - \\
\hline Colletotrichum sp.3 & - & - & - & - & - & - & - & - & 10 & - & - & - & - & - & - & - & - \\
\hline Colletotrichum sp. 4 & - & - & - & - & - & - & - & - & - & - & - & - & 8 & 15 & 10 & 37 & - \\
\hline Glomerella sp. & 12 & - & - & 16 & - & - & - & 8 & - & - & - & - & - & - & - & - & - \\
\hline Pestalotia $\mathrm{sp}$ & 6 & 1 & 1 & - & 10 & 3 & 2 & - & 5 & 2 & 1 & - & - & 8 & - & 1 & - \\
\hline Phomopsis sp. & - & - & - & - & 4 & - & - & - & - & - & - & - & - & - & - & - & - \\
\hline Phoma sp. & - & - & - & - & 4 & - & - & - & 12 & - & - & - & - & - & - & - & - \\
\hline Paecilomyces sp. & - & - & - & - & 3 & - & - & - & 2 & - & - & - & - & - & - & - & - \\
\hline
\end{tabular}




\begin{tabular}{|c|c|c|c|c|c|c|c|c|c|c|c|c|c|c|c|c|c|}
\hline \multirow{2}{*}{ Endophytic fungi } & \multicolumn{4}{|c|}{ LBG* } & \multicolumn{4}{|c|}{ MCF } & \multicolumn{5}{|c|}{ KIF } & \multicolumn{4}{|c|}{ BDA } \\
\hline & $\mathbf{L}^{* *}$ & $\mathbf{S}$ & B & $\mathbf{R}$ & $\mathbf{L}$ & $\mathbf{S}$ & B & $\mathbf{R}$ & $\mathbf{L}$ & $\mathbf{S}$ & $\mathbf{B}$ & $\mathbf{R}$ & Se & $\mathbf{L}$ & $\mathbf{S}$ & B & $\mathbf{R}$ \\
\hline \multicolumn{18}{|l|}{ Hyhpomycetes } \\
\hline Acremonium sp. & 3 & - & - & - & 7 & - & - & - & - & - & - & - & - & - & - & - & - \\
\hline Alternaria sp. & - & - & - & - & - & - & - & - & - & - & - & - & - & 4 & - & - & - \\
\hline Aschochyta sp. 2 & - & - & - & - & - & 2 & - & - & - & - & - & - & - & - & - & - & - \\
\hline Aschochyta sp. 2 & - & - & - & - & - & - & - & - & - & - & - & - & - & 8 & - & - & - \\
\hline Aspergillus sp. & - & - & - & - & 8 & 4 & 10 & 7 & - & - & - & 10 & - & - & - & - & - \\
\hline Aspergillus flavus & 11 & - & - & - & 3 & & - & - & - & 9 & 4 & - & - & - & - & - & - \\
\hline A. niger & 10 & - & 14 & - & 6 & 3 & - & - & 4 & 6 & - & - & - & - & - & - & - \\
\hline A. fumigatus & - & - & - & - & - & - & - & - & 4 & & 8 & 6 & 4 & 8 & 4 & 6 & 7 \\
\hline A. nidulans & - & - & - & - & 3 & - & - & - & - & - & - & - & - & - & 8 & - & 9 \\
\hline A. terreus & - & - & - & - & 3 & 15 & - & - & - & - & - & - & 24 & - & - & - & - \\
\hline Bispora sp. & - & 7 & - & - & - & - & - & - & - & - & - & - & - & - & - & - & - \\
\hline Cephalosporium sp. & 5 & - & - & - & 14 & - & - & - & - & - & - & - & - & - & - & - & - \\
\hline Cladosporium sp. & - & 7 & - & - & - & - & - & - & - & 4 & - & - & - & - & - & - & - \\
\hline Curvularia sp. 1 & 12 & 24 & - & - & - & - & - & - & - & - & - & - & - & - & - & - & - \\
\hline Curvularia sp. 2 & - & - & - & - & 13 & - & 7 & - & - & - & - & - & - & - & - & - & - \\
\hline Curvularia sp. 3 & - & - & - & - & - & - & - & - & 18 & 10 & 8 & - & - & - & - & - & - \\
\hline Curvularia sp. 4 & - & - & - & - & - & - & - & - & - & - & - & - & - & 8 & 8 & - & - \\
\hline Fusarium sp. 1 & 15 & & - & - & 15 & - & - & - & 20 & - & - & - & - & - & - & - & 13 \\
\hline Fusarium sp. 2 & - & - & - & - & - & - & - & - & 15 & - & - & - & - & - & - & - & 10 \\
\hline Geotrichum sp. & 5 & - & - & - & - & - & - & - & - & - & - & - & - & - & - & - & - \\
\hline Gloeosporium sp. & 2 & - & - & - & - & - & - & - & - & - & - & - & - & - & - & - & - \\
\hline Gloecephalis sp. & - & - & 4 & - & - & - & 2 & - & - & - & - & - & - & - & - & - & - \\
\hline Gliocladium sp. & - & - & - & - & - & - & - & 8 & - & - & - & - & - & 14 & 2 & & 2 \\
\hline Mycogone sp. & 5 & - & - & - & - & - & - & - & - & - & - & - & - & - & - & - & - \\
\hline Nigrospora sp & 5 & - & - & - & 10 & - & - & - & - & - & - & - & - & - & - & - & - \\
\hline Oidium sp. & 5 & - & - & - & - & - & - & - & - & - & - & - & - & - & - & - & - \\
\hline Penicillium sp. & - & - & - & - & - & - & 2 & - & - & - & - & - & - & - & - & - & - \\
\hline Phyllosticta sp. & - & - & - & - & - & 4 & - & - & - & - & - & - & - & - & - & - & - \\
\hline Trichoderma sp. 1 & - & - & 8 & 5 & - & - & - & - & - & - & - & - & - & - & - & - & - \\
\hline Trichoderma sp. 2 & - & - & - & - & 3 & - & 18 & 25 & - & - & - & - & - & - & - & - & - \\
\hline Trichoderma sp. 3 & - & - & - & - & - & - & - & - & 4 & 11 & 24 & 19 & - & - & - & - & - \\
\hline Trichoderma sp. 4 & - & - & - & - & - & - & - & - & & & & & - & 25 & 16 & 8 & - \\
\hline Trichoderma sp. 5 & - & - & - & - & - & - & - & - & 4 & 4 & 4 & 16 & - & - & - & - & - \\
\hline Trichoderma sp. 6 & - & - & - & - & - & - & - & - & - & - & - & - & - & 15 & - & 4 & - \\
\hline
\end{tabular}

\section{Mycelia sterilia}

Mycelia sterilia 1

Mycelia sterilia 2

Mycelia sterilia 3

Mycelia sterilia 4

Mycelia sterilia 5

(P001)

Mycelia sterilia 6

Mycelia sterilia 7

Mycelia sterilia 8

Mycelia sterilia 9

Mycelia sterilia 10

Mycelia sterilia 11

Mycelia sterilia 12

*Provenances $-\mathrm{LBG}=$ Limbe Botanic Garden, $\mathrm{MCF}=$ Mount Cameroon Forest, KIF = Kilum Ijim Forest, BDA= Bamendankwe;

**Prunus parts $-\mathrm{L}=$ Leaf, $\mathrm{S}=$ Stem, $\mathrm{B}=$ Bark, $\mathrm{R}=\mathrm{Root}, \mathrm{Se}=$ Seed. 
Table 3. The percentage dominance of endophytic fungi from all segments of four Prunus africana provenances from Cameroon.

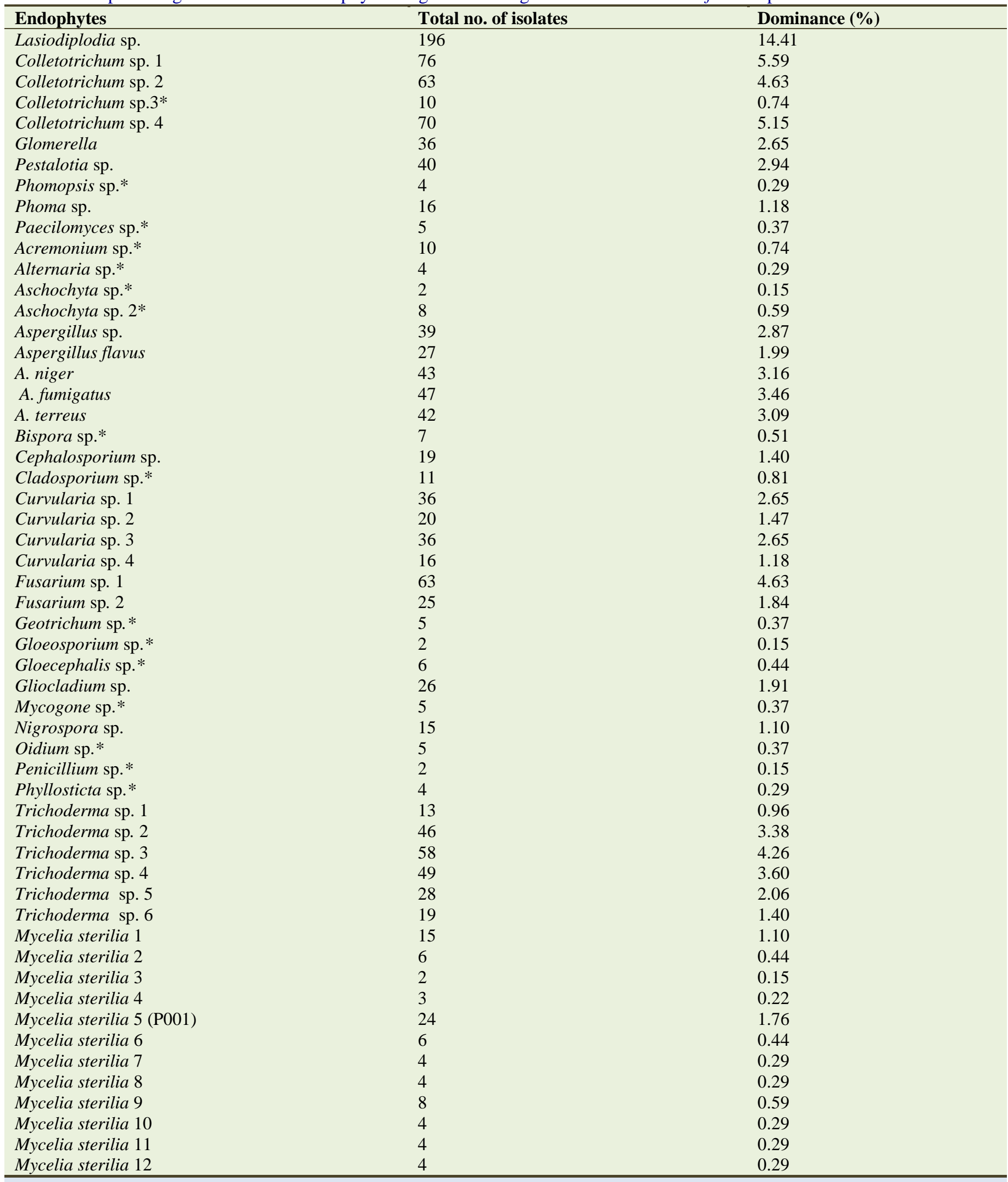

*Rare taxa with CF $<1 \%$ 
Table 4. Dominant endophytic fungal species across and in each of four provenances from Cameroon.

\begin{tabular}{|c|c|c|c|c|}
\hline Provenance & Dominant Species & Total & Isolation rate & CF (\%) \\
\hline \multirow[t]{9}{*}{ All } & Lasiodiplodia $\mathrm{sp}$ & 196 & 0.14 & 14.41 \\
\hline & Colletotrichum sp. 1 & 76 & 0.06 & 5.59 \\
\hline & Colletotrichum sp. 2 & 63 & 0.05 & 4.63 \\
\hline & Fusarium sp. 1 & 63 & 0.05 & 4.63 \\
\hline & Trichoderma 3 & 58 & 0.04 & 4.26 \\
\hline & Aspergillus fumigatus & 47 & 0.03 & 3.46 \\
\hline & Pestalotia $\mathrm{sp}$ & 40 & 0.03 & 2.94 \\
\hline & Curvularia sp, 1 & 36 & 0.03 & 2.65 \\
\hline & Mycelia sterilia 5 & 24 & 0.02 & 1.76 \\
\hline \multirow[t]{6}{*}{ LBG } & Colletotrichum sp. 1 & 76 & 0.24 & 23.75 \\
\hline & Curvularia sp, 1 & 36 & 0.11 & 11.25 \\
\hline & Aspergillus. niger & 24 & 0.08 & 7.50 \\
\hline & Fusarium sp. 1 & 15 & 0.05 & 4.69 \\
\hline & Lasiodiplodia sp & 15 & 0.05 & 4.69 \\
\hline & Trichoderma sp 1 & 13 & 0.04 & 4.06 \\
\hline \multirow[t]{6}{*}{ MCF } & Lasiodiplodia $\mathrm{sp}$ & 79 & 0.25 & 24.69 \\
\hline & Colletotrichum sp. 2 & 63 & 0.20 & 19.69 \\
\hline & Trichoderma sp 2 & 46 & 0.14 & 14.38 \\
\hline & Aspergillus sp. & 29 & 0.09 & 9.06 \\
\hline & Curvularia sp, 2 & 20 & 0.06 & 6.25 \\
\hline & Fusarium sp. 1 & 15 & 0.05 & 4.69 \\
\hline \multirow[t]{8}{*}{ KIF } & Lasiodiplodia sp & 66 & 0.17 & 16.50 \\
\hline & Trichoderma sp 3 & 58 & 0.15 & 14.50 \\
\hline & Curvularia sp, 3 & 36 & 0.09 & 9.00 \\
\hline & Aspergillus terreus & 24 & 0.06 & 6.00 \\
\hline & Aspergillus. fumigatus & 22 & 0.06 & 5.50 \\
\hline & Fusarium sp. 1 & 20 & 0.05 & 5.00 \\
\hline & Mycelia sterilia 5 & 14 & 0.04 & 3.50 \\
\hline & Colletotrichum sp.3 & 10 & 0.03 & 2.50 \\
\hline \multirow[t]{6}{*}{ BDA } & Colletotrichum sp. 4 & 62 & 0.19 & 19.38 \\
\hline & Trichoderma sp 4 & 49 & 0.15 & 15.31 \\
\hline & Lasiodiplodia $\mathrm{sp}$ & 36 & 0.11 & 11.25 \\
\hline & Aspergillus fumigatus & 25 & 0.08 & 7.81 \\
\hline & Gliocladium $\mathrm{sp}$ & 18 & 0.06 & 5.63 \\
\hline & Curvularia sp, 4 & 16 & 0.05 & 5.00 \\
\hline
\end{tabular}

LBG = Limbe Botanic Garden, MCF = Mount Cameroon Forest, KIF = Kilum-Ijim Forest, BDA= Bamendankwe.

\section{Spatial structure of endophytic fungi}

The percentage contribution by the dominant endophytes to the endophyte assemblages in tissues of $P$. africana from the different provenances are shown in Table 5. The overall dominant species were Lasiodiplodia sp., Colletotrichum sp. 1, Colletotrichum sp. 2, Fusarium sp. and Trichoderma sp. In the Limbe Botanic Garden provenance, Colletotrichum sp. 1 and Curvularia sp. 1 were the dominant species while Lasiodiplodia sp. and Colletotrichum sp. 2 were the dominant species in the Mount Cameroon forest provenance (Table 5). Lasiodiplodia sp. and
Trichoderma sp. 3 were the most dominant species in Kilum-Ijim Forest, while in the Bamendankwe provenance, Colletotrichum sp. 4 and Trichoderma sp. 4 were the most dominant. The colonization frequency, dominance and species richness of endophytic fungi obtained from the different provenances is shown on Table 6. The species richness ranged from 26 species for Bamendankwe to 50 for Mount Cameroon.

\section{Tissue specificity of endophytic fungi}

The leaf samples from each provenance showed more diversity, higher isolation rate of endophytic fungi 
than the bark, stem, roots and seeds (Table 6). Higher isolation rate was also recorded for stems, roots from Mount Cameroon Forest (MCF). In contrast, higher isolation rates occurred in bark from Bamendankwe (BDA) and lowest from Limbe Botanic Garden (LBG).

Table 5. Percentage contribution by the dominant endophytes to the endophyte assemblages in tissues of $P$. africana at provenance.

\begin{tabular}{|c|c|c|c|}
\hline Provenance* & Tissue part & Dominant Endophyte & Contribution (\%) \\
\hline \multirow{4}{*}{ LBG } & Leaf & Colletotrichum sp. 1 & 13.22 \\
\hline & Stem & Colletotrichum sp. 1 & 41.79 \\
\hline & Bark & Aspergillus niger & 43.75 \\
\hline & Root & Colletotrichum sp. 1 & 60.38 \\
\hline \multirow{4}{*}{ MCF } & Leaf & Lasiodiplodia sp. & 16.39 \\
\hline & Stem & Lasiodiplodia sp. & 38.20 \\
\hline & Bark & Trichoderma sp. 2 & 28.13 \\
\hline & Root & Trichoderma sp. 2 & 33.33 \\
\hline \multirow{5}{*}{ KIF } & Leaf & Lasiodiplodia sp. & 22.54 \\
\hline & Stem & Trichoderma sp. 3 & 23.91 \\
\hline & Bark & Trichoderma sp. 3 & 43.64 \\
\hline & Root & Trichoderma sp. 4 & 25.68 \\
\hline & Seed & Lasiodiplodia sp. & 37.84 \\
\hline \multirow{4}{*}{ BDA } & Leaf & Trichoderma sp. 4 & 21.01 \\
\hline & Stem & Trichoderma sp. 5 & 25.81 \\
\hline & Bark & Colletotrichum sp. 4 & 50.00 \\
\hline & Root & Fusarium sp. 1 & 31.71 \\
\hline
\end{tabular}

*LBG= Limbe Botanic Garden, MCF = Mount Cameroon Forest, KIF = Kilum-Ijim Forest, BDA= Bamendankwe.

Table 6. Dominant Endophytes, species richness and percentage colonization (CF\%) of $P$. africana from different provenances in Cameroon.

\begin{tabular}{|c|c|c|c|c|c|}
\hline Provenance* & Tissue type*** & Total isolates & CF (\%) & Dominance of fungi & Species richness \\
\hline \multirow{4}{*}{ LBG } & $\mathbf{L}$ & 123 & 9.04 & 9.07 & 16 \\
\hline & $\mathbf{S}$ & 67 & 4.93 & 4.94 & 5 \\
\hline & B & 32 & 2.35 & 2.36 & 5 \\
\hline & $\mathbf{R}$ & 53 & 3.90 & 3.91 & 3 \\
\hline \multirow[t]{3}{*}{ Total } & & 275 & 20.22 & 20.28 & 29 \\
\hline & $\mathbf{L}$ & 183 & 13.46 & 13.50 & 23 \\
\hline & $\mathbf{S}$ & 89 & 6.54 & 6.56 & 11 \\
\hline \multirow[t]{2}{*}{ MCF } & B & 64 & 4.71 & 4.72 & 8 \\
\hline & $\mathbf{R}$ & 75 & 5.51 & 5.53 & 8 \\
\hline \multirow[t]{3}{*}{ Total } & & 411 & 30.22 & 30.31 & 50 \\
\hline & $\mathbf{L}$ & 140 & 10.29 & 10.32 & 13 \\
\hline & $\mathbf{S}$ & 46 & 3.38 & 3.39 & 7 \\
\hline \multirow{3}{*}{ KIF } & B & 55 & 4.04 & 4.06 & 7 \\
\hline & $\mathbf{R}$ & 59 & 4.34 & 4.35 & 6 \\
\hline & Se & 74 & 5.44 & 5.46 & 6 \\
\hline \multirow[t]{3}{*}{ Total } & & 374 & 27.50 & 27.58 & 39 \\
\hline & $\mathbf{L}$ & 119 & 8.75 & 8.78 & 11 \\
\hline & $\mathbf{S}$ & 62 & 4.56 & 4.57 & 9 \\
\hline \multirow[t]{2}{*}{ BDA } & B & 74 & 5.44 & 5.46 & 6 \\
\hline & $\mathbf{R}$ & 41 & 3.01 & 3.02 & 5 \\
\hline Total & & 296 & 21.76 & 21.83 & 31 \\
\hline
\end{tabular}


The diversity indices and evenness of the endophytic fungal communities from the various parts of the host at different locations are listed in Table 7. In each of the sites, the highest diversity of endophytic fungi occurred in the leaves, while the roots had the lowest diversity. The seeds from Kilum-Ijim Forest had diversity indices comparable to those of roots. The leaves from Bamendankwe recorded the highest species evenness (0.94) while the lowest was in the roots (0.67) from Mount Cameroon Forest.
The inter-site comparison between the endophytes composition recovered from the different locations using Sörensen's similarity coefficients (Cs) ranged from 0.22 to 0.46 (Table 8). The highest similarity coefficient (0.46) was observed for the fungal communities between Mount Cameroon Forest and Mount Kilum-Ijim Forest, followed by Mount Cameroon Forest and Limbe Botanic Garden $(\mathrm{Cs}=0.44)$. The similarity coefficient between Mount Cameroon Forest and Bamendankwe and between Botanic Garden and Bamendankwe were quite low.

Table 7. Diversity indices and evenness of endophytic fungi from four provenances of $P$. africana tissues from Cameroon.

\begin{tabular}{lllll}
\hline \multirow{2}{*}{ Provenance* } & Tissue type** & Diversity Index & Evenness \\
\cline { 3 - 4 } & LBG & Shannon-Wiener & Simpson's & \\
& S & 2.60 & 0.92 & 0.94 \\
& B & 1.51 & 0.75 & 0.94 \\
MCF & R & 1.37 & 0.71 & 0.85 \\
& L & 0.89 & 0.54 & 0.81 \\
& S & 2.82 & 0.92 & 0.89 \\
& B & 1.88 & 0.78 & 0.78 \\
KIF & R & 1.81 & 0.81 & 0.87 \\
& L & 1.40 & 0.83 & 0.67 \\
& S & 2.31 & 0.88 & 0.90 \\
& B & 1.82 & 0.82 & 0.94 \\
BDA & R & 1.62 & 0.74 & 0.83 \\
& Se & 1.62 & 0.77 & 0.90 \\
& L & 1.49 & 0.73 & 0.83 \\
& S & 2.26 & 0.88 & 0.94 \\
& B & 2.01 & 0.85 & 0.92 \\
& R & 1.35 & 0.67 & 0.75 \\
\end{tabular}

*LBG = Limbe Botanic Garden, MCF = Mount Cameroon Forest, KIF = Kilum-Ijim Forest, BDA= Bamendankwe; **L = Leaf, $\mathrm{S}=$ Stem, B = Bark, $\mathrm{R}=$ Root, $\mathrm{Se}=$ Seed.

Table 8. Sörensen's similarity coefficient for Endophytes in P. africana from different provenances in Cameroon.

\begin{tabular}{lllll}
\hline Provenances* & LBG & MCF & KIF & BDA \\
\hline LBG & 1.00 & 0.44 & 0.33 & 0.22 \\
MCF & & 1.00 & 0.46 & 0.29 \\
KIF & & & 1.00 & 0.38 \\
BDA & & & & 1.00 \\
\hline
\end{tabular}

*LBG = Limbe Botanic Garden, MCF = Mount Cameroon Forest, KIF = Kilum Ijim Forest, BDA= Bamendankwe.

The patterns of endophyte assemblages on species incidence and abundance on various organ types of $P$. africana among sites based on simple correspondence analysis are illustrated on Fig. 2. The ordination shows distinct clusters within organs, and among sites thus demonstrating that clear differences between experimental groups exist. The first two principal axes explain above $84.34 \%$ of the inertia (a measure of association) or variation of the endophytes for all sites. In comparison of all the sites; the two principle axes explain
$73.38 \%$ (X-axis: $40.50 \%$, Y-axis: $32.88 \%) ; 73.39 \%(\mathrm{X}$ axis: $39.95 \%$, Y-axis: $33.44 \%$ ) of the variability in the species abundance and incidence pattern respectively. The ordination on the $\mathrm{X}$-axis and $\mathrm{Y}$-axis create distinct clusters of sites with Mount Cameroon Forest and Mount Kilum-Ijim Forest clustering closely together showing close similarity of fungal communities in terms of abundance. Many cosmopolitan species were found scattered between sites. In the Y-axis, fungal species in Limbe Botanic Garden and Bamendankwe were clearly 
separated signifying differences in their fungal communities. Similar results of distinct clusters of the four different sites in relation to species incidence were observed on the ordination on the $\mathrm{X}$ and $\mathrm{Y}$ axes. However on the Y-axis Mount Cameroon Forest was clearly separated from Mount Kilum-Ijim Forest. Also, Mount Kilum-Ijim Forest appeared to be closely similar to Bamendankwe and Mount Cameroon Forest while Limbe Botanic Garden remained distinct. Fewer cosmopolitan species were observed.
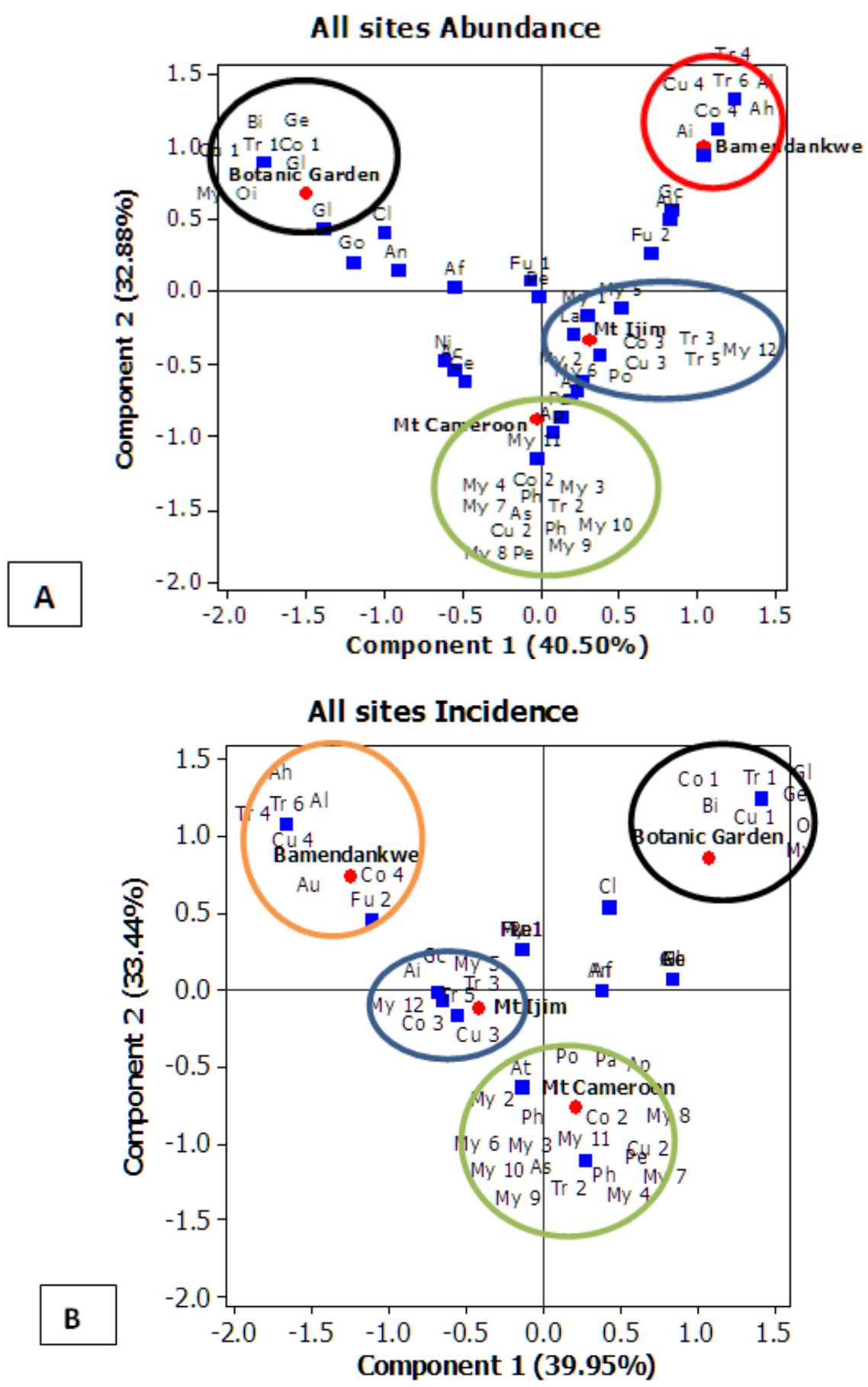

Fig. 2: Two-dimensional correspondence ordination of endophytic communities on P. africana from all sites A. Abundance, B. Incidence. Diagram oriented at x- and y-axes. The combinations of letters on the scatter plots encode the association of the endophytic species. Sites are shown as: a, Limbe Botanic Garden; b, Mount Cameroon Forest; c, Mount Kilum-Ijim Forest; d, Bamendankwe $\boldsymbol{m}=$ the colonization frequency of the endophytic species. 


\section{Discussion}

All the tissues of $P$. africana examined were found to harbour endophytic fungi with 27 fungal genera identified. This number is similar to endophytic genera from Citrus limon (Douanla-Meli et al., 2013) and Kigelia pinnata (Maheswari and Rajagopal, 2013), other tropical trees. The number is however higher than what was reported for Prunus avium and Prunus dosmestica (Pimenta et al., 2012) and 18 taxa from Azadirachta indica (Verma et al., 2007). The overall colonization and isolation rates of endophytes from $P$. africana were high compared to those reported for Diospyros crassiflora (Douanla-Meli and Langer, 2012) but similar to that of $C$. limon (Douanla-Meli et al., 2013) and Centella asiatica (Rakotoniriana et al., 2008). Such variations or differences in the species composition of the endophytic assemblage according to host species may be attributed to factors such as difference in sampling size made in each study, site characteristics elevation, exposure, associated vegetation, tissue type and age (Fisher et al., 1994; Rodrigues, 1994) as well as the physical and chemical status of the tissues, growth stage and position in the canopy for large woody perennials (Suryanarayanan et al., 2002).

The endophytic assemblages of $P$. africana comprised a number of cosmopolitan endophyte species such as Colletotrichum sp., Aspergillus sp., Trichoderma sp., Lasiodiplodia sp., Curvularia sp., Fusarium sp. and Pestalotia sp., which have previously been reported as common endophytes of tropical, subtropical or temperate plants (Kumaresan and Suryanarayanan, 2001; Arnold et al., 2003; Arnold and Lutzoni, 2007; Kumar and Hyde, 2004). The most common endophyte, Colletotrichum, recorded in this study has also been reported as the most common endophyte in tropical plants such as Theobroma cacao (Arnold et al., 2003), D. crassiflora (Douanla-Meli and Langer, 2012), and Citrus limon (Douanla-meli et al., 2013).

Other cosmopolitan genera with less than $1 \%$ of isolation frequency such as Phoma, Phomopsis, Penicillium, Geotrichum, Gloeosporium, Phyllosticta, Oidium, Mycogone, Gloecephalis, Geotrichum, Bispora, Aschochyta, Acremonium and Paecilomyces, have been isolated as endophytes from a wide range of different host plants (Kumaresan and Suryanarayanan, 2001; Cannon and Simmons, 2002). Generally, the assemblage of endophytes for a given host comprises a relatively consistent group of fungal taxa and species, characterized by a few dominant species, and this study also corroborates this conclusion (Carroll, 1995).

The dominance of Hyphomycetes in this study also corroborates the findings of Verma et al. (2007) and Vega et al. (2010) who found that Hyphomycetes dominated the endophyte communities of tropical plants. Sterile mycelia consist of various morphological fungal types without any true spores. These fungi are considerably prevalent in endophytic investigations (Lacap et al., 2003) as was observed in this study. The percentage of Mycelia sterilia in this study is similar to the $23.6 \%$ reported for Tripterygium wilfordii (Kumar and Hyde 2004) but higher than the endophytes from Azadirachta indica (7.7\%) (Verma et al., 2007), and lower than that of Centella asiatica (10.3\%) (Rakotoniriana et al., 2008).

A single host species is infected with a qualitatively similar assembly of endophytes over its natural host range. However the relative abundance of particular species may differ depending on the location (Fisher et al., 1994; Petrini et al., 1992). This was observed in this study where more colonization frequency, isolation rate, species richness and dominance of endophytes were recorded in Mount Cameroon Forest than the other locations. This site-specific trend has been previously reported for different plant species (Petrini and Petrini, 1985; Herre et al., 2007; Hoffman and Arnold, 2008; Vega et al., 2010). In another perennial tropical crop, Theobroma cacao, Arnold et al. (2003) reported a reduction in similarity among endophytes as distance between sampling sites increased $>50 \mathrm{~km}$. Santamaria and Bayman (2005) also reported significant differences in coffee fungal endophytes in Puerto Rico across different sites. Ecological factors such as differences in environmental conditions or presence of inoculum, the degree of disturbance of habitats (Taylor et al., 1999) in which the host grows may have played some role in the disparity in the type and number of fungi from those sites (Arnold and Lutzoni, 2007). The variation may also be as a result of genetic variation within and among populations of $P$. africana (Dawson and Powell, 1999). The lower incidence of infection by the more cosmopolitan species in native site may be as a result of exclusion by the more specialized host-specific endophytes since the cosmopolitan species are also present in these sites (Hoffman and Arnold, 2008).

The endophyte assemblage of the different organ types showed that several endophytic fungi were common in 
more than one organ. Analysis of endophytic species composition and colonization frequencies in leaf, stem, bark, root and seeds are characterized by different endophytic populations. In the present study, leaf tissues showed highest infection frequency as well as highest species diversity of endophytes as has been reported in most studies (Gazis and Chaverri, 2010; Vega et al., 2010; Dounla-meli and Langer, 2012). This is indicative of tissue specificity or recurrence which may reflect their capacity for utilizing or surviving within a specific substrate as has been widely observed (Fisher and Petrini, 1990, 1992; Rajagopal and Suryanarayanan, 2000; Gond et al., 2007; Verma et al., 2007; Maheswari and Rajagopal, 2013). Such a qualitative difference in the recruitment of endophytic fungi in leaf and other tissues might depend on, apart from other factors, the physical and chemical status of the tissues. These endophytes in these tissues could reflect the prevalence of aerial spores at a particular site, the ability of spores of individual species to grow into the tissues, and presence of favorable conditions that allow ambient microfungi to enter internal plant tissues. Moreso leaves offer a much greater surface area for inoculum capture (Wilson and Carroll, 1994). Leaves also contain mainly parenchymatous cells that are thin-walled, with chloroplasts and rich in starch, whereas the other tissues for example bark tissue is covered with periderm which mainly strengthens the plant than supplying nutrient elements on which the endophyte depends. In addition to these factors, endophytes are known to produce several different types of secondary metabolites (Schulz et al., 2002) whose metabolic activity in the leaf tissue can influence its physiological status or may reflect their capacity for utilizing or surviving within a specific substrate (Rajagopal et al., 2010). Variations in endophytic assemblage from a single host in different study sites comprises a relatively consistent group of fungal taxa and species, characterized by a few dominant species (Bills and Pollishook, 1992) and this study also supports this conclusion (Carroll, 1995), as Lasiodiplodia sp was the dominant species isolated from all tissues except the roots. Colletotrichum sp., Trichoderma sp., Fusarium sp. were recorded as the most dominant species with different frequencies occurring in the different tissues at each site. The dominant species in leaves stems and barks of $P$. africana were not very different. For example, Lasiodiplodia sp. was the dominant species in leaf and stems of Mount Cameroon Forest and was also the dominant species in the leaf and seed of Mount KilumIjimForest. Colletotrichum sp. was the dominant endophytes in the leaf, stem and roots in Limbe Botanic Garden and bark in Bamendankwe. Trichoderma sp. was also the dominant species in all the other tissues in all the sites except for the roots in Bamendankwe which harbored Fusarium sp. Similar findings were obtained in case of D. crassiflora (Dounla-meli and Langer, 2012). This indicates the ability of some endophytes to move from one part to another part of the host (Fisher et al., 1995).

In comparison to other tissues/organs, only five genera were recovered from the seeds with lower diversity and different assemblage. Similar results have been recorded for T. cacao (cacoa) and T. grandiflorum trees (Hanada et al., 2010; Vega et al., 2010). Suryanarayanan and Vijaykrishna (2001) and Kumar and Hyde (2004) stated that the overall tissue-recurrence is mainly based on the species composition and frequency that are known to vary with different tissues of the hosts. Based on this concept, Petrini et al. (1992) stated that plant organs resemble distinct microhabitats with reference to endophyte infections as observed in this study.

Shannon-Wiener indices indicate that the diversity of endophytes in P. africana at all the locations were more in the leaves with highest recorded from Mount Cameroon due to more number of species than in the other tissues. The lowest endophyte diversity was from roots in Limbe Botanic Garden. This is similar to the value of obtained from the leaves of three-year-old Panax quinquefolium (American ginseng) when compared with other ages (Xing et al., 2010) and those of leaves of Quercus liaotungensis (Fagaceae) and Ulmus macrocarpa (Ulmaceae), when compared with twigs (Sun et al., 2012). The Shannon index takes into account the number and the evenness of the species, the index therefore increased either by having additional unique species, or by having higher species evenness (Banerjee et al., 2008). Similarly, Collado et al. (2000) also reported higher diversity indices of endophytic fungi in leaves of Quercus ilex than in twigs. However, Shannon-Wiener index showed that the diversity of endophytes in Kigelia pinnata is more in the leaves (3.015) than the bark (2.593) (Maheswari and Rajagopal, 2013). In contrast, the Shannon-Wiener diversity indices of endophytic fungi in four age groups of Panax quinquefolium (American ginseng) in the roots ranged from $2.094-2.798$ (Xing et al., 2010). The species richness of endophytes in the tissues at the four locations differed with the highest recorded in the leaves. 
On the other hand, the Simpson's diversity index ranged from 0 to 1 , whereby, the larger index value proportionally reflects the lower species diversity. For instance, leaves from Mount Cameroon Forest had the maximum Simpson's index, i.e., a lower diversity for the leaf samples.

Though Simpson diversity does not show much variation in the tissues, there was however some variation in evenness index, in all the tissues indicating that uniform occurrence of various species is prevalent in some locations than others. Evenness values varied mainly due to the unequal distribution of individuals and account for rare species (Maheswari and Rajagopal, 2013).

Though the dominance and diversity indices are high in the leaves than in the other tissues, the evenness index is higher in root and lower in the leaves due to the frequent isolation of Colletotrichum sp., Lasiodiplodia sp., Pestalotiopsis sp., Trichoderma sp. and rare appearance of other taxa in the leaf tissues.

Despite some variations in the specific recovery of the endophytic community from plant tissues in each location, the inter-site comparisons in terms of similarity index showed low similarity between locations in this study. This is similar to similarity index between locations for Terminalia arjuna (Tejesvi et al., 2005) and similarities (Cs) of endophytic fungal composition among four ages of American ginseng (Xing et al., 2010). Certain environmental conditions such as site characteristics such as elevation, humidity, exposure, associated vegetation, tissue type may account for these relationships (Fisher et al., 1994; Verma et al., 2007).

For all the sites, the ordination creates distinct clusters thus demonstrating that clear differences between taxa groups in different localities exist. Mount Cameroon Forest and Mount Kilum-Ijim Forest clustered closely together and represented the same endophyte community type due the high presence of Lasiodiplodia sp and Trichoderma sp. Both Limbe Botanic Garden and Bamendankwe were found outside the related community clusters of Loc 2 and 3. This was as a result of the presence of Colletotrichum sp, Trichoderma $\mathrm{sp}$ and Fusarium sp and other rare species/cosmopolitan endophyte species. Similar results have been obtained by Brown et al. (1998) who demonstrated clear distinctions between endophytic communities, and thus, variability between endophytic communities of the $M$. acuminata species complex.

\section{Conclusion}

This is the first intensive survey on the diversity and distribution of fungal endophytes of $P$. africana. The 1358 isolates from 1360 segments cultured were identified to 27 genera. Location wise, Mount Cameroon Forest harboured more endophyte species than the other localities while the leaf dominated other tissues in number of endophytes harboured. This has demonstrated that fungal endophytes densely inhabit $P$. africana tissues and that spatial structure tends to influence the species composition. This study also suggests a complex interaction between the tree and its fungal inhabitants. Such interactions among endophytes may also underlie the difference in species composition and structure in the plant tissues. Although this study has increased the known diversity of endophytes, only further sampling through other methods other than culture dependent and molecular studies will allow precise estimates, identification, as well as a better understanding of the community assemblage, especially niche partitioning within this plant. Furthermore, the broad diversity of these fungi represented in this study as well as their easy access makes them interesting in pursuing natural product (secondary metabolites) screening program.

\section{Conflict of interest statement}

Authors declare that they have no conflict of interest.

\section{Acknowledgement}

We thank the Institute of Agricultural Research for Development, (IRAD) Ekona, Cameroon particularly the staff of the Rubber Pathology Laboratory for all laboratory assistance, Mola Jackai for assisting in collecting the samples from the fields. This research was supported by BUNS, Cameroon.

\section{References}

Aly, A.H., Debbab, A., Kjer, J., Proksch, P., 2010. Fungal endophytes from higher plants: a prolific source of phytochemicals and other bioactive natural products. Fungal Divers. 41, 1-16.

Arnold, A. E., Mejia, L. C., Kyllo, D., Rojas, E., Maynard, Z., Robbins, N., Herre, E. A., 2003. Fungal endophytes limit pathogen damage in a tropical tree. Proc. Natl. Acad. Sci. (USA). 100, 
15649-15654.

Arnold, A. E., Lutzoni, E., 2007. Diversity and host range of foliar fungal endophytes. Are tropical leaves biodiversity hotspots? Ecology. 88, 541-549.

Arnold, A. E., Maynard, Z., Gilbert, G., 2001. Fungal endophytes in dicotyledonous neotropical trees: patterns of abundance and diversity. Mycol. Res. 105, 1502-1507.

Arnold, A. E., Maynard, Z., Gilbert, G., Coley, P. D., Kursar, T.A., 2000. Are tropical fungal endophytes hyperdiverse? Ecol. Lett. 3, 267-274.

Banerjee, T., Srivastava, R. K., Melkania, U., 2008. Floral distribution pattern in surroundings of SIDCUL IIE-Pantnagar. In: Biodiversity, Environment and Sustainability (Ed.: Singh, J.). MD Publications Pvt. Ltd., New Delhi. pp.181-189.

Barnett, H. L., Hunter, B. B., 1998. Illustrated Genera of Imperfect Fungi. $4^{\text {th }}$ Edn. Burgess Pub., Minneapolis, USA. 218p.

Bills, G. F., Pollishook, J. D., 1992. Recovery of endophytic fungi from Chamaecyparis thyoides. Sydowia. 44, 1-12.

Bombardelli, E., Morazzoni, P., 1997. Prunus africana (Hook. f) Kalkm. Fitoterapia. 68, 205-218.

Brown, K. B., Hyde, K. D., Guest, D. I., 1998. Preliminary studies on endophytic fungal communities of Musa acuminata species complex in Hong Kong and Australia. Fungal Divers. 1, 27-51.

Cannon, P. F., Simmons, C. M., 2002. Diversity and host preference of leaf endophytic fungi in the Iwokrama Forest Reserve, Guyana. Mycologia. 94(2), 210-220.

Carroll, G., 1995. Forest endophytes: Pattern and process. Can. J. Bot. 73, 1316-1324.

Collado, J., Platas, G., Pelaez, F., 2000. Host specificity in fungal endophytic populations of Quercus ilex and Quercus faginea from Central Spain. Nova Hedwigia. 71, 421-430.

Cunningham, A. B., Mbenkum, F.T., 1993. Sustainability of Harvesting Prunus africana Bark in Cameroon. A Medicinal Plant in International Trade. People and Plants working paper 2. UNESCO, Paris.

Cunningham, M., Cunningham, A. B., Schippmann, U., 1997. Trade in Prunus africana and the implementation of CITES. German Federal Agency for Nature Conservation, Bonn, Germany.

Dawson, I. K., Powell, W., 1999. Genetic variation in the Afromontane tree Prunus africana, an endangered medicinal species. Mol. Ecol. 8, 151156.
Dawson, I., Were, J., Lengkeek, A., 2000. Conservation of Prunus africana, An Over-exploited African Medicinal Tree. Forest Genetic Resources 28 in UNEP-WCMC 2007.

Douanla-Meli, C., Langer, E., 2012.Diversity and molecular phylogeny of fungal endophytes associated with Diospyros crassiflora. Mycology. 3, 175-87.

Douanla-Meli, C., Langer, E., Talontsi, M. F., 2013. Fungal endophyte diversity and community patterns in healthy and yellowing leaves of Citrus limon. Fungal Ecol. 16, 212-222.

Ewusi, B. N., Asanga, C. A., Eben Ebai, S., Nkongo, J. B. N., 1992. An Evaluation of the Quantity and Distribution of Pygeum africanum on the Slopes of Mount Cameroon. Report for Plantecam-Medicam, Douala, Cameroon.

Ewusi, B. N., Tako, C. T., Nyambi, J., Acworth, J., 1997. Bark extraction: Current situation and sustainable cropping of Prunus africana on Mount Cameroon. Unpublished paper. Mount Cameroon Project, Limbe, Cameroon.

Fisher, P. J., Petrini, L. E., Sutton, B. C., Petrini, O., 1995. A study of fungal endophytes in leaves, stems and roots of Gynoxis oleifolia Muchler (Compositae) from Ecuador. Nova Hedwigia. 60, 589-594.

Fisher, P. J., Petrini, O., Petrini, L. E., Sutton, B. C., 1994. Fungal endophytes from the leaves and twigs of Quercus ilex L. from England, Majorca and Switzerland. New Phytol. 127, 133-137.

Fisher, P. J., Petrini, O., 1990. A comparative study of fungal endophytes in xylem and bark of Alnus species in England and Switzerland. Mycol. Res. 94, 313-319.

Fisher, P. J., Petrini, O., 1992. Fungal saprobes and pathogens as endophytes of rice (Oryza sativa L.). New Phytol. 120, 137-143.

Fourneau, C., Hocquemille, R., Cavé, A., 1996. Triterpenes from Prunus Africana bark. Phytochemistry. 42, 1387-1389.

Gazis, R., Chaverri, P., 2010. Diversity of fungal endophytes in leaves and stems of wild rubber trees (Hevea brasiliensis) in Peru. Fungal Ecol.3, 240-54.

Gond, S.K., Verma, V.C., Kumar, A., Kumar, V., Kharwar, R.N., 2007. Study of endophytic fungal community from different parts of Aegle marmelos Correae (Rutaceae) from Varanasi (India). World J. Microbiol. Biotechnol. 23, 1371-1375

Hanada, R. E., Pomella, A. W. V., Costa, H. S., Bezerra, J. L., Loguercio, L. L., Pereira, J. O., 2010. 
Endophytic fungal diversity in Theobroma cacao (cacao) and $T$. grandiflorum (cupuaçu) trees and their potential for growth promotion and biocontrol of black-pod disease. Fungal Biol. 114, 901-910.

Herre, E. A., Mejia, L. C., Kyllo, D., Rojas, E. I., Maynard, Z.., 2007. Ecological implications of antipathogen effects of tropical fungal endophytes and mycorrhizae. Ecology. 88, 550-558.

Hoffman, M., Arnold, A. E., 2008. Geography and host identity interact to shape communities of endophytic fungi in cupressaceous trees. Mycol. Res. 112, 331344.

Ingram, V., 2007. Prunus Platform Meeting Report. SNV, Bamenda

Kharwar, R. N., Mishra, A., Gond, S. K., Stierle, A., Stierle, D., 2011. Anticancer compounds derived from fungal endophytes: their importance and future challenges. Nat. Prod. Rep. 28, 1208-1228.

Kumar, D. S. S., Hyde, K. D., 2004. Biodiversity and tissue-recurrence of endophytic fungi in Tripterygium wilfordii. Fungal Divers. 17, 69-90.

Kumaresan, V., Suryanarayanan, T. S., 2001. Occurrence and distribution of endophytic fungi in a mangrove community. Mycol. Res. 105, 1388-1391.

Kusari, S., Hertweck, C., Spitellert, M., 2012. Chemical ecology of endophytic fungi: origins of secondary metabolites. Chem. Biol. 19, 792-798.

Lacap, D. C., Hyde, K. D., Liew, E. C. Y., 2003. An evaluation of the fungal 'morphotype' concept based on ribosomal DNA sequences. Fungal Divers. 12, 53-66.

Maheswari, S., Rajagopal, K., 2013. Biodiversity of endophytic fungi in Kigelia pinnata during two different seasons. Curr. Sci. 104(4), 1-4.

Petrini, L., Petrini, O., 1985. Xylariaceous fungi as endophytes. Sydowia. 38, 216-234.

Petrini, O., Fisher, P. J., Petrini, L. E., 1992. Fungal Endophytes of bracken (Pteridium aquilinum) with some reflection on their use in biological control. Sydowia. 44, 282-293.

Photita, W. P., Taylor, W. J., Ford, R., Hyde, K. D., Lumyong, S., 2005. Morphological and molecular characterization of Colletotrichum species from herbaceous plants in Thailand. Fungal Divers. 18, 117-133.

Pielou, E. C., 1974 Population and Community Ecology: Principles and Methods. Gordon and Breach, New York. 424p.

Pimenta, R. S., Moreira Da Silva, J. F., Buyer, J. S., Wojciech, J. J., 2012. Endophytic fungi from plums (Prunus domestica) and their antifungal activity against Monilinia fructicola. J. Food Prot. 75(10), 1883-1889.

Rajagopal, K., Kalavathy, S., Kokila, S., Kathiravan, G., Prasad, R., Balasubramanian, P., 2010. Diversity of fungal endophytes in few medicinal herbs of South India. Asian J. Exp. Biol. 1(2), 415-418.

Rajagopal, K., Suryanarayanan, T. S., 2000. Isolation of endophytic fungi from leaves of neem (Azadirachta indica A. Juss). Curr. Sci. 78, 13751378.

Rakotoniriana, F., Munaut, C., Decock, D., Randriamampionona, M., Andriambololoniaina, T., Rakotomalala, E. J., Rakotonirina, C., Rabemanantsoa, K., Cheuk, S. U., Ratsimamanga, J., Mahillon, M., El-Jaziri, J., Quetin-Leclercq, A., Corbisier, M., 2008. Endophytic fungi from leaves of Centella asiatica: Occurrence and potential interactions within leaves. Antonie van Leeuwenhoek. 93, 27-36.

Rodrigues, K. F., 1994. The foliar fungal endophytes of the Amazonian palm Euterpe oleracea. Mycologia. 86, 376-385.

Santamaria, J., Bayman, P., 2005. Fungal epiphytes and endophytes of coffee leaves (Coffea arabica). Microbial Ecol. 50, 1-8.

Schippmann, U., 2001. Medicinal plants Significant Trade study Bonn, Germany: German Federal Agency for Nature Conservation. CITES Project S109. Plants Committee Document PC9 9.1.3 (rev.).

Schulz, B., Wanke, U., Draeger, S., Aust, H. J., 1993. Endophytes from herbaceous plants and shrubs effectiveness of surface sterilization methods. Mycol. Res. 97, 1447-1450.

Schulz, B., Boyle, C., Draeger, S., Rommert, A. K., Krohn, K., 2002. Endophytic fungi: a source of novel biologically active secondary metabolites. Mycol. Res. 106, 996-1004.

Stewart, K., 2001. The Commercial Bark Harvest of the African Cherry (Prunus africana) on Mount Oku, Cameroon: Effects of Traditional Uses and Population Dynamics. $\mathrm{PhD}$ thesis, Florida International University. Available online at http://digitalcommons.fiu.edu/dissertations/AAI300 6865 Abstract viewed 26 July 2007.

Stewart, K., 2003. The African Cherry (Prunus africana): Can lessons be learned from an overexploited medical tree? J. Ethnopharmacol. 89, 3-13.

Strobel, G. A., 2002. Microbial gifts from rain forests. Can. J. Plant Pathol. 24, 14-20.

Strobel, G. A., Daisy, B. H., Castillo, U., Harper, J., 2004. Natural products from endophytic 
microorganisms. J. Nat. Prod. 67, 257-268.

Sun, X., Dinga, Q., Hyde, K. D., Guo, L. D., 2012. Community structure and preference of endophytic fungi of three woody plants in a mixed forest. Fungal Ecol. 5 (5), 624-632.

Sunderland, T. C. H., Obama, C., 1999. A preliminary survey of the non-wood forest products of Equatorial Guinea. In: The Non-wood Forest Products of Central Africa: Current Research Issues and Prospects for Conservation and Development (Eds.: Sunderland, T.C.H., Clark, L.E.). Food and Agriculture Organisation, Rome.

Suryanarayanan, T. S., Murali, T. S., Venkatesan, G., 2002. Occurrence and distribution of fungal endophytes in tropical forests across a rainfall gradient. Can. J. Bot. 80, 818-826.

Suryanarayanan, T. S., Vijaykrishna, D., 2001. Fungal endophytes of aerial roots of Ficus benghalensis. Fungal Divers. 8, 155-161.

Taylor, J. E., Hyde, K. D., Jones, E. B. G., 1999. Endophytic fungi associated with the temperate palm, Trachycarpus fortunei, within and outside its natural geographic range. New Phytol. 142, 335346.

Tejesvi, M.V., Mahesh, B., Nalini, M. S., Prakash, H. S., Kini, K. R., Subbiah, V., Shetty, H. S., 2005. Endophytic fungal assemblages from inner bark and twig of Terminalia arjuna W. and A. (Combretaceae). World J. Microbiol. Biotechnol. 21, 1535-1540.

Vega, F. E. A., Simpkins, M. C., Aime, F., Posada, S. W., Peterson, S. A., Rehner, F. I., Castillo, A., Arnold, A. E., 2010. Fungal endophyte diversity in coffee plants from Colombia, Hawaii, Mexico and Puerto Rico. Fungal Ecol. 3(3), 122-138.

Vega, F. E., Posada, F., Peterson, S.W., Gianfagna, T., Chaves, F., 2006. Penicillium species endophytic in coffee plants and ochratoxin A production. Mycologia. 98, 31-42.

Verma, V. C., Gond, S. K., Kumar, A., Kharwar, R. N., Strobel, G., 2007. The endophytic mycoflora of bark, leaf, and stem tissues of Azadirachta indica A. Juss. (Neem) from Varanasi (India). Microbial Ecol. $54,119-125$.

Watanabe, T., 2002. Pictorial Atlas of Soil and Seed Fungi: Morphologies of Cultured Fungi and Key to Species. $2^{\text {nd }}$ Edn. CRC Press, Boca Raton, FL.

Wilson, D., Carroll, G.C., 1994. Infection studies on Discula quercina, an endophyte of Quercus garryana. Mycologia. 86(5), 635-647

Xing, X., Guo, S., Fu, J., 2010. Biodiversity and distribution of endophytic fungi associated with Panax quinquefolium L. cultivated in a forest reserve. Symbiosis. 51(2), 161-166.

\section{How to cite this article:}

Ntuba-Jua, G. M., Mih, A. M., Bechem, E. E. T., 2017. Diversity and distribution of endophytic fungi in different Prunus africana (Hook. f.) Kalkman Provenances in Cameroon. Int. J. Curr. Res. Biosci. Plant Biol. 4(6), 7-23. doi: https://doi.org/10.20546/ijcrbp.2017.406.002 